\title{
IMPLEMENTATION OF DIVERSIFICATION STRATEGY ON FARMS IN THE CZECH REPUBLIC
}

\author{
J. Huml, L. Vokáčová, Š. Kala
}

Received: December 17, 2010

\begin{abstract}
HUML, J., VOKÁČOVÁ, L., KALA, Š.: Implementation of diversification strategy on farms in the Czech Republic. Acta univ. agric. et silvic. Mendel. Brun., 2011, LIX, No. 2, pp. 109-114

Nowadays, it is not easy to achieve prosperity and flourishing progress of an agriculture company. The owners and managers engaged in agricultural sector are thus forced to face increased challenge as for the search of new and more stable sources of income. Employing the strategy of diversification represents one of the possible ways aiming to improve the current situation. Moreover, this strategy also provides important tool for enhancing the quality of rural infrastructure and creation of job opportunities in non-traditional sectors and thus makes for the decrease in jobs in the agricultural sector. The study of secondary sources and in-depth interviews with successful diversification project managers allowed the analysis of prospective usage of the diversification strategy in agricultural companies.
\end{abstract}

diversification strategy, agriculture, risk

Despite the fact that the application of diversification strategy in agriculture does not represent any new phenomenon it is regarded as one of the possible approaches enabling the improvement of both European and Czech agriculture, with the prospective usage especially in small and medium-sized enterprises. Generally speaking, diversification strategy may be ranged along with the strategies of direct expansion and vertical integration among corporate growth strategies that are focused on expanding company's business activities.

The aim of this contribution is to define the notion of diversification in agriculture, to determine the degree of implementation of diversification strategy by agricultural enterprises in the Czech Republic, and to identify the crucial factors influencing the decision making of owners and managers of agricultural enterprises concerning their diversification activities.

\section{METHODS AND RESOURCES}

Diversification as the possible strategy of agricultural enterprises for building competitive advantage began to gain popularity in the EU in the eighties of the twentieth century. The reasons that made farm- ers use this strategy stemmed from still more significant rate of environmental changes, impacts of globalization (Ilbery, 1998), from gradual increase in surplus production of a wide range of agricultural commodities that was accompanied by problem with sale and price lowering of these commodities, and from transformation of Common Agricultural Policy of the EU.

Tichá and Hron (2007) understand the diversification strategy as a growth strategy and they claim that it is employed in case that the possibilities of development within the frame of existing business activities are limited. They distinguish three types: concentric diversification that consists in the production of new products and services related to the present activity of a businessman; horizontal that is based on the production of new products and services which does not relate to the present activity of a businessman but which are offered to current customers; conglomerate that is founded on the production of new products and services which does not relate to company present activity. Veber (1998), Robbins and Coulter (2004) make difference between related or vertical diversification linked with the development of business activities in different 
but related domains, and unrelated or lateral diversification associated with the development of business activities in non-related domains.

Similar division though with the use of different terminology is employed by Bělohlávek, Koštan and Šuleř (2006) who define concentric diversification as a growth strategy using the existing company strengths. Concentric diversification is thus to a considerable extent focused on the optimal use of existing production factors or those which represent company competitive advantage. Within the conglomerate diversification the company concentrates on the production of non-related products. The primary evaluative criterion is then the return on investment, whereas similarity or continuity with the current business activities is not taken onto account.

Since the whole process of the formulation and the choice of strategy proceeds according to Štůsek (2008) under the conditions of uncertainty and risk it is possible to make generalizations of business strategic approaches only at the expense of substantial simplification of reality. Every business plan and therefore the related strategies as well are based on an original idea or concept. The degree of originality or creative invention is important and decisive as for the success of business plan or strategy. The choice of particular type of strategy for business plan realization out of the generalized "list of strategies" may serve only as abstract or methodical base for the elaboration of the key idea (Koráb, Peterka, Režňáková, 2007).

In agricultural sector three fundamental approaches toward diversification strategy have been employed. The first one understands the diversification as a possibility for farmers to make use of various sources of income (Prag, 2002). The second approach aims at the exploration of the opportunities of using farm's capital or farm's factors of production which were initially used within farm's conventional agricultural activities on other profit making activities endeavouring its most effective exploitation (Winter, Turner et al., 2002). Ilbery (1991) considers farmers as businessmen but he emphasizes the use of factors of production which were originally acquired for the purposes of agricultural production within the frame of non-agricultural business activities. The third approach defines diversification in the sense of new farmer's business activity whose aim is to prosper from the identified profit opportunity. Neither the degree of interconnection with farmer's existing agricultural activity, nor the use of current farm's factors of production is at the same time relevant: it does not represent a restrictive condition (Hron et al., 2007). Definition of diversification as farmer's plan to carry out new business activity which he associates with profit opportunity allows us to understand farmers as businessmen as well as it facilitates further definition of the notion of diversification and it enables us to answer the question of why farmers should employ the strategy of diversification. For we may analogously raise a question: why should farmers run a business? Legitimacy of this view on diversification is confirmed also by Turner et al. (2006) who argues that the implementation of a diversification business plan of an agricultural businessman is not in the basic principles different from the preparation and realization of a business plan of other businessman in another domain of business. Considering the exception resulting from special circumstances it is possible to assume that these activities will require expenditures for the purchase of factors of production. They will as well require new knowledge and the ability to control the process of production in which he was not so far engaged. He will be thus proving his business and managerial abilities.

Results and conclusions of this contribution were formulated on the grounds of methods of exploratory research, system analogies and that of logic deduction. Necessary data were obtained from technical literature, from Farm structure survey in 2003, 2005 and 2007, and from questioning as a method of primary data gathering. Structured individual indepth interviews with managers and owners of agricultural enterprises that adopted diversification business projects were carried out. The structure of interview was based upon the recommended methodical technique for preparation and realization of business plans and their division (see Fotr, 1999) into individual pre-investment, investment and operational stages. The representative set included 50 units whereas the selection criterion was the already realized diversification project.

\section{RESULTS AND DISCUSSION}

It is possible to reveal the level of diversification (or the level of specialization) within the conventional agricultural activities from the specialization of agricultural enterprises in the Czech Republic. In 2007 approximately $40 \%$ of enterprises were engaged in plant production, $30 \%$ in animal production and $30 \%$ in combined animal and plant production. The decrease by $8 \%$ in comparison with the year 2005 was recorded with combined plant and animal production (FSS, 2007). In terms of the structure of individual specializations it can be stated that there is currently fewer enterprises with combined production in favour of enterprises specialized in both plant and animal production.

A more detailed survey (see Fig. 1) recorded approximately $20 \%$ of enterprises primarily engaged in plant production and $8 \%$ of them mainly engaged in animal production in 2007. In addition to this, approximately $20 \%$ of enterprises engaged in plant production and $22 \%$ of enterprises engaged in animal production were narrowly specialized.

There was not a huge discrepancy between the number of narrowly specialized enterprises engaged in either plant or animal production. Nevertheless, with respect to different number of enterprises engaged in plant and animal production, it is possible to assume that enterprises engaged in animal production are relatively more often specialized 


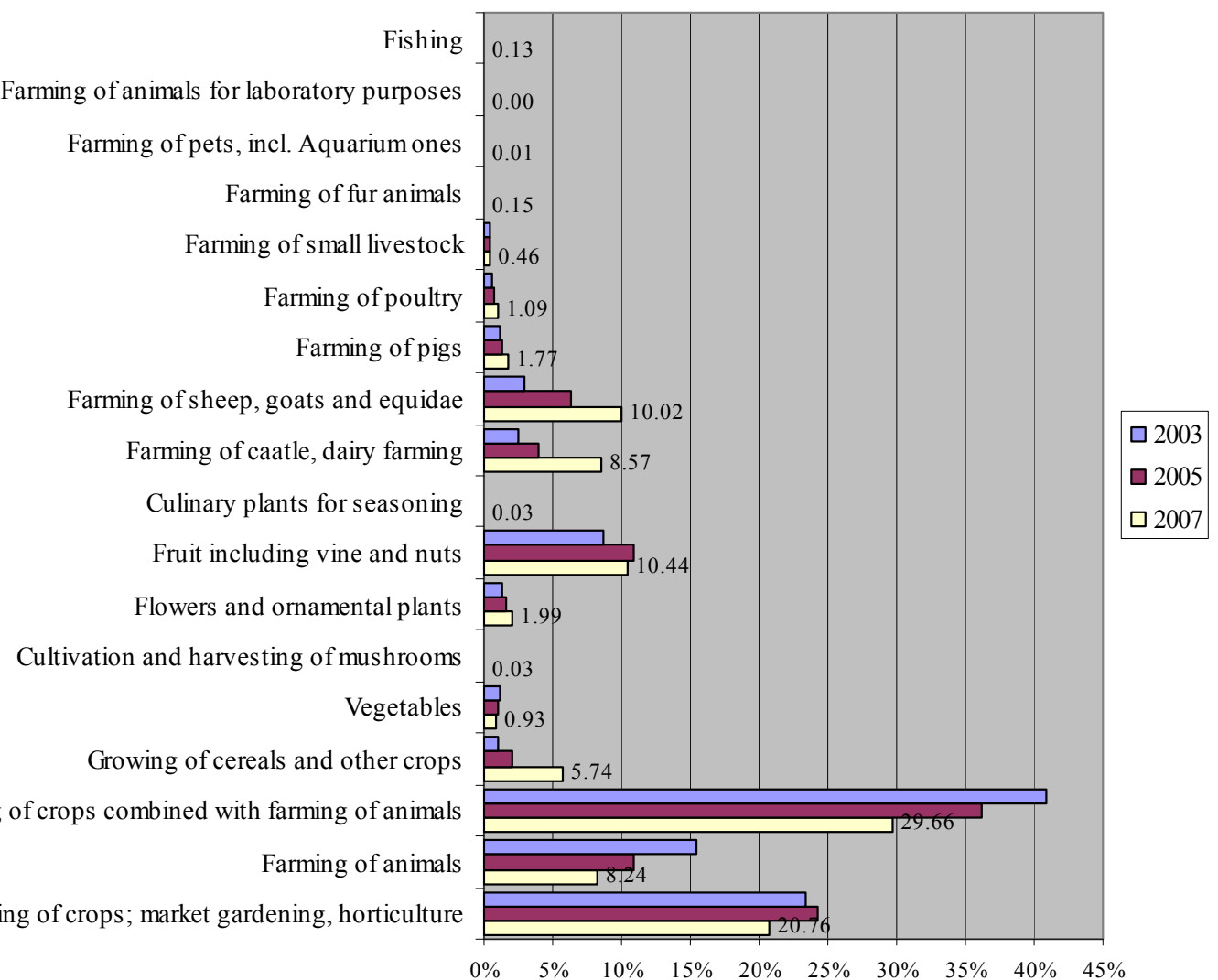

1: Production specialization of agricultural enterprises in the Czech Republic

(Source: Czech Statistical Office, Farm Structure Survey)

(72.80 of enterprises in AP compared with $49.9 \%$ of narrowly specialized enterprises in $\mathrm{PP}$ ). The predominant sphere of orientation within narrowly specialized enterprises engaged in animal production is represented by sheep and goat breeding, horse breeding (10.0\%) and cattle breeding (8.5\%). These specializations recorded the most significant increase in comparison with the previous monitored periods. Narrowly specialized enterprises most commonly focus on the cultivation of fruit including grapevine and nuts $(10.4 \%)$ and on the cultivation of cereals and other cultivated plants including hop plant (5.7\%).

The degree of implementation of diversification may also be demonstrated by the development of agricultural enterprises producing their own products and providing services (see Fig. 2).

The biggest increase within a five year period was recorded by the domain of agricultural services for the customer (from 1020 to 1375), agro-tourism (from 89 to 223), sporting activities in the country (from 55 to 165) and grapevine processing (from 177 to 881). By contrast, the decrease in the number of enterprises was recorded in the domain of potato and cereal processing.

Another possibility represents the monitoring of non agricultural activities of agricultural enterprises in favour of rural development where it is possible to include all gainful occupations lacking the char- acter of agricultural employment and which brings economic benefit for the unit (except for the activities realized purely for the profit of one's own farming). It may be stated (Chart I) that in 2007, only 4366 (i.e. 11.4\%) of enterprises was besides agriculture engaged in the only one gainful occupation and that 386 of enterprises was engaged in several non agricultural activities.

The most common non agricultural activities represent (within the category of Other) trade, transport, construction activity and energy production (39.1\%). The second rank with $18.8 \%$ is occupied by processing of agricultural products and the third position belongs to tourism achieving 13.0\%.

Following the previous results, it may be argued that the diversification strategy within the scope of conventional agricultural production finds broad use thanks to general pattern of both plant (creation of crop methods) and combined production of agricultural enterprises. As for the activities of non agricultural character, diversification strategy concerns only $12 \%$ of agricultural enterprises though over the monitored period there is a noticeable influence of the position of agriculture in the national economy of the Czech Republic, the conception of agrarian policy and the support for the "Rural development programme of the Czech Republic for period 20072013". The questions of what makes some enterprises adopt the strategy of diversification and what 


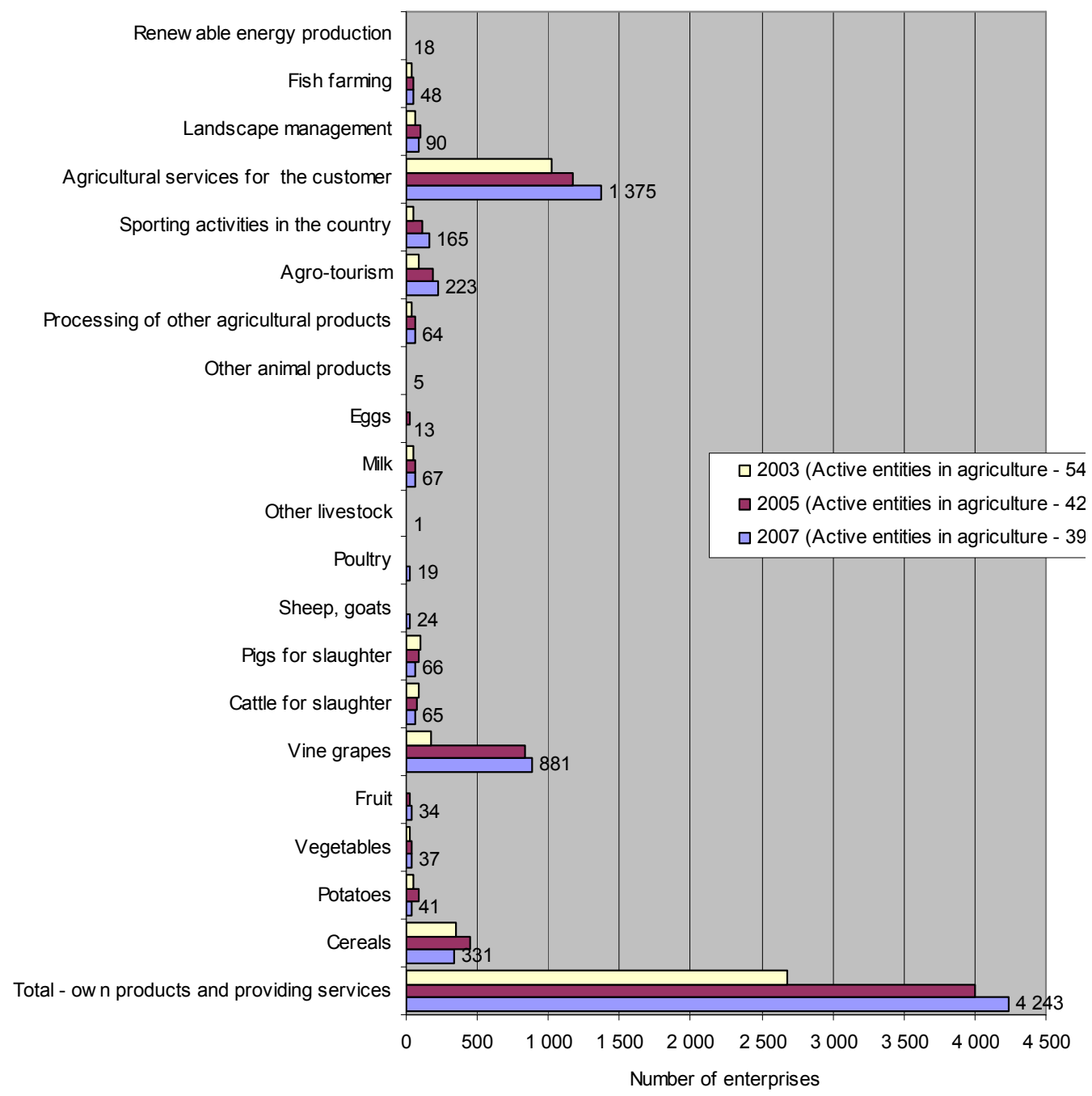

2: Numbers of enterprises producing their own products and providing services (Source: Czech Statistical Office, Farm Structure Survey)

I: Non agricultural activities for rural development 2007

\begin{tabular}{lc}
\hline \multicolumn{1}{c}{ Non agricultural activities for rural development } & Number of rural units [RU] \\
\hline RU without non agricultural activities & 33645 \\
RU carry out the only non agricultural activity & 4366 \\
RU carry out several non agricultural activities & 386 \\
Tourism, accommodation and other activities for leisure time & 684 \\
Handicraft & 372 \\
Processing of farm product & 988 \\
Wood processing & 490 \\
Aquaculture & 47 \\
Renewable energy production & 45 \\
Contractual work & 668 \\
Other & 1963 \\
\hline
\end{tabular}

(Source: Czech Statistical Office, Farm Structure Survey) 
factors influence the decision concerning the diversification remain. Interviews with successful individuals that have carried out this strategy enable us to divide these factors exerting an influence on the decision about the diversification into external and internal factors.

External factors include agrarian policy, rural development policy and institutional support. The presence of some of these factors does not usually exert the greatest impact on farmer's decision to diversify the production but it can facilitate the realization of diversification process. This category further includes factors such as market opportunity (or market problems) and specific territorial factors. For instance in mountain areas there is usually biggest ratio of touristic and accommodation services whereas near metropolitan areas it is possible to search for opportunities for the sales of own products directly to the end consumer.

Internal factors are represented by general farm characteristics such as size and type, structure of assets and production, the degree of use of factors of production, and indebtedness ratio. Although it may seem that diversification will be favoured by bigger enterprises due to larger capacity of resources, it was revealed that it is more likely the choice of medium sized enterprises. Small enterprises prefer production diversification focused on the production of special products while the big enterprises give their priority to various services. The second group of internal factors influencing the decision whether to approach the diversification of production or not is represented by culture, education and personal characteristics of people working on this farm.

With regard to the nature of diversification, it is obvious that in connection with the realization of the strategy problems may occur. Within the process of opportunity identification, the possible obstruction may be uncertain state backing in the Czech Republic and the consequent administrative processes and conservative attitude of the country towards adoption of novelties.

During the process of project preparation (planning), the most significant obstruction may become ambiguity as for the definition of objectives. Objectives are often set as short-term goals which may be achieved within the operational scope. Long-term and strategic objectives are regarded as goals that are determined with great difficulty and that are exceedingly abstract and hardly practically usable for the operation itself. Scepticism as for the business project emerges as well as fear in terms of the ability to raise necessary financial resources for project realization. Important role play the barriers resulting from the unfamiliarity with business sector and the possible lack of professional knowledge. Agricultural businessmen most commonly rely on themselves or on family members and they acquire expert knowledge by self-study. It is equally common that they establish cooperation with an expert in this domain or with some other farmer or with someone who had already carried out such project. Further obstacles may be linked with bureaucracy and the necessary administrative load during the preparatory stage of the project as well as the defined conditions as for the sanitation, the veterinary surgeons, the fire brigade etc.

Wide range of various problems at the beginning of the realization stage may go from the elemental problems such as the character and the market demand force for the given product or service (mistakes in the carried out marketing research) through the skills and business experience (competence, skills, approach to and knowledge of sources of information and financial resources) up to legal restrictions (sanitary regulations, protection of public health etc.).

During the realization and evaluation process of diversification strategy projects it is especially the problem linked with financing that emerges (maintaining the level of investment, cash flow problems). Moreover, recruiting and the ability to retain knowledgeable and skilful employees may represent another problem.

The reasons which make some businessmen terminate the diversified activity usually stem from business failure and difficulties, problems linked with demanding expertise requirements, abandoning the business, problems resulting from legal regulations and illness of bred animals. Other reasons for the termination or interruption of the strategy realization may be the following problems: insufficient return on investment, decline on the demand side, change in legal regulations, businessman lacking time, family problems or change of family situation, problems with employees or lack of resources.

\section{SUMMARY}

Even after the accession of the Czech Republic to the EU the sector of agricultural production does not represent stable business domain. Within this context, farmers are forced to face increased challenge as for the search of new and more steady sources of income. One of the possible solutions may be embodied by the implementation of the strategy of diversification promoting the development of an agricultural enterprise or the exploitation of diversification opportunities which conceals significant space for the improvement of the quality of rural infrastructure and creation of new job opportunities in non-traditional sectors and thus makes for the decrease in jobs in agricultural sector. 
The presented text defines the notion of diversification from the perspective of three fundamental approaches. Following the structural results of the agriculture of the Czech Republic, it establishes the degree of implementation of the strategy of diversification by agricultural enterprises and it identifies the crucial factors influencing the decision making process of owners and managers of agricultural enterprises as far as diversification activities are concerned.

\section{REFERENCES}

BĚLOHLÁVEK, F., KOŠŤAN, P., ŠULEŘ, O., 2006: Management. Brno: Computer Press. ISBN 80-2510396-X.

Český statistický úřad, 2008: Strukturální výsledky za zemédélství v roce 2007. Praha. [on-line]. [cit. 2010-10-21]. Dostupné z URL http://www.czso.cz/ csu/2008edicniplan.nsf/p/2126-08.

Český statistický úřad, 2006: Strukturální výsledky za zemédèlství v roce 2005. Praha. [on-line]. [cit. 2010-10-21]. Dostupné z URL http://www.czso. cz/csu/2006edicniplan.nsf/publ/2126-06-v_ roce_2005.

Český statistický úřad, 2004: Strukturální výsledky za zemédélství v roce 2003. Praha. [on-line]. [cit. 2010-10-21]. Dostupné z URL http://www.czso. $\mathrm{cz/csu/2004edicniplan.nsf/publ/2126-04-v_{- }}$ roce $\_2003$.

FOTR, J., 1999: Podnikatelský plán a investiční rozhodování. Praha: Grada Publishing. ISBN 80-7169404-5.

HRON, J., ŠTŮSEK, J., ARNOŠT, M., HUML, J., PLATILOVÁ-VORLÍČKOVÁ, L., 2007: Diversification - strategy of building the competitive advantage in agribusiness. Agriculture Economics Czech. 53 (12). 531-538. ISSN 0139-570X.

KORÁB, V., PETERKA, J., REŽŇÁKOVÁ, M., 2007: Podnikatelský plán. Brno: Computer Press. ISBN 978-80-251-1605-0.
ILBERY, B., 1998: The Geography of Rural Change. Essex: Addison-Wesley Longman. 267 s. ISBN-10: 0-582-27724-8.

ILBERY, B. W., 1991: Farm Diversification as an adjustment strategy on the Urban. Fronte of the West Midlands. Journal of Rural Studies, 7 (3): 207-218.

PRAG, P., 2002: Rural Diversification. London: Estate Gazette. ISBN 0-7282-0371-5.

ROBBINS, S. P., COULTER, M., 2004: Management. Praha: Grada Publishing. 600 s. ISBN 80-247-04951.

ŠTŮSEK, J. a kol., 2008: Modely strategického myšlení $v$ agribusinessu. Lanškroun: TG TISK. ISBN 978-80903680-8-8.

TICHÁ, I., HRON, J., 2007: Strategické rízení. Praha: PEF ČZU v Praze. ISBN 978-80213-0922-7.

TURNER, M., WHITEHEAD, I., BARR, D., HOWE, K., 2006: The Effects of Public Funding on Farmer's Attitudes to Farm Diversifiation. London: Department for Environment Foods and Rural Affairs.

VEBER, J. a kol., 1998: Management. Praha: Vysoká škola ekonomická v Praze. 168 s. ISBN 80-7079406-2.

WINTER, D. M., TURNER, M., BARR, D., ERRINGTON, A., ROBERTY, M., LOBLEY, M., REED, M., 2002: Farm Diversification Activities: Benchmarking study 2002. Final report to DEFRA. Centre for Rural Research, University of Exeter \& Rural Tourism Research Group, University of Plymouth.

Ing. Jan Huml, Ing. Lucie Vokáčová, Ing. Štěpán Kala, MBA, Katedra řízení, Provozně ekonomická fakulta, Česká zemědělská univerzita v Praze, Kamýcká 129, 16521 Praha 6-Suchdol, Česká republika, e-mail: huml@pef.czu.cz,vokacova@pef.czu.cz, kalas@pef.czu.cz 